\title{
Geotechnical parameters of limestone from the Topola Formation in the area of Topola Village, Kavarna Municipality (NE Bulgaria)
}

\author{
Rosen Nankin ${ }^{1}$, Miroslav Krastanov ${ }^{1}$ \\ ${ }^{I}$ Geological Institute, Bulgarian Academy of Sciences, Acad. G. Bonchev Str., Bl. 24, 1113 Sofia, Bulgaria; \\ e-mails: miro_k@geology.bas.bg,r_nankin@mail.bg
}

(Accepted in revised form: November 2017)

\begin{abstract}
The area around Topola Village is affected by landslide processes, which are the major factor in the formation of the modern relief. The terrains affected by the landslides are mainly composed of sediments of the Topola Formation. In the engineering-geological studies carried out in the region, main attention was paid to the geotechnical parameters of aragonite sediments and calcareous clays of the Topola Formation. The purpose of this article is to define the geotechnical parameters of the micritic limestones from this formation, which have a major stabilizing role on the lands affected by landslide processes. The mean values of bulk density, compressive strength and tensile strength of these rocks were determined. The quadratic deviation, the coefficient of variation, and the calculation value of the individual parameters, with confidence at $90 \%$, $95 \%$ and $99 \%$, respectively, were also calculated.
\end{abstract}

Nankin, R., Krastanov, M. 2017. Geotechnical parameters of limestone from the Topola Formation in the area of Topola Village, Kavarna Municipality. Geologica Balcanica 46 (2), 83-86.

Keywords: Landslide, Topola Formation, limestone, geotechnical parameters.

\section{INTRODUCTION}

The studied area covers a part of the Black Sea coast, located between the villages of Topola and Bozhurets, Kavarna Municipality, NE Bulgaria (Fig. 1). The Black Sea coast is one of the regions of Bulgaria where landslide processes occur periodically. Favorable conditions for these dangerous geological phenomena are the geological-tectonic structures and the geomorphological properties of rocks and soils (Ivanov et al., 2014). Amongst the rocks, namely the sediments of the Topola Formation play the major role in the formation of landslides in the area. For this reason, these materials are of considerable interest for applied geological investigations. Previous studies on the Topola Formation (e.g., Koleva-Rekalova et al., 1996, 1999; Ivanov et al., 2014) have shown that the aragonite sediments and calcareous clays, and to a lesser extent the limestones that compose this sedimentary unit, are the main rock types that are affected by landslides. This paper aims to clarify the geotechnical parameters of these sediments, on which future predictions of occurrence and identification of instability could be based.

\section{GEOMORPHOLOGICAL AND GEOLOGICAL SETTING}

The area of this study is situated within the southeastern periphery of the Dobrudza Plateau, as the terrain is modeled by abrasion, erosion and gravitational processes (Frangov and Krastanov, 2015). There are some localities that evolved into linearly oriented stairs and hills of varying heights (Fig. 1). The coastal slope of the Dobrudza Plateau has an average width of 600-800 m and ends with steep, in many places up to vertical, slope. The terrain is often cut across by deep ravines. The latter drain a significant portion of the karst and fracture waters of the plateau. The slope of the plateau is non-draining, shaped depression with permanent or temporary marshes.

The region is composed of Quaternary and Neogene sediments (Cheshitev et al., 1991, 1995). The Quaternary is represented by deluvial-proluvial and gravel-sandy clays with small thicknesses. The Neogene is composed of the Euxinograd, Topola and Karvuna formations. The Euxinograd Formation is built up mainly of gray, gray-blue and ochre sandy and clayey siltstones and silty clays, containing Diatomaceae and 


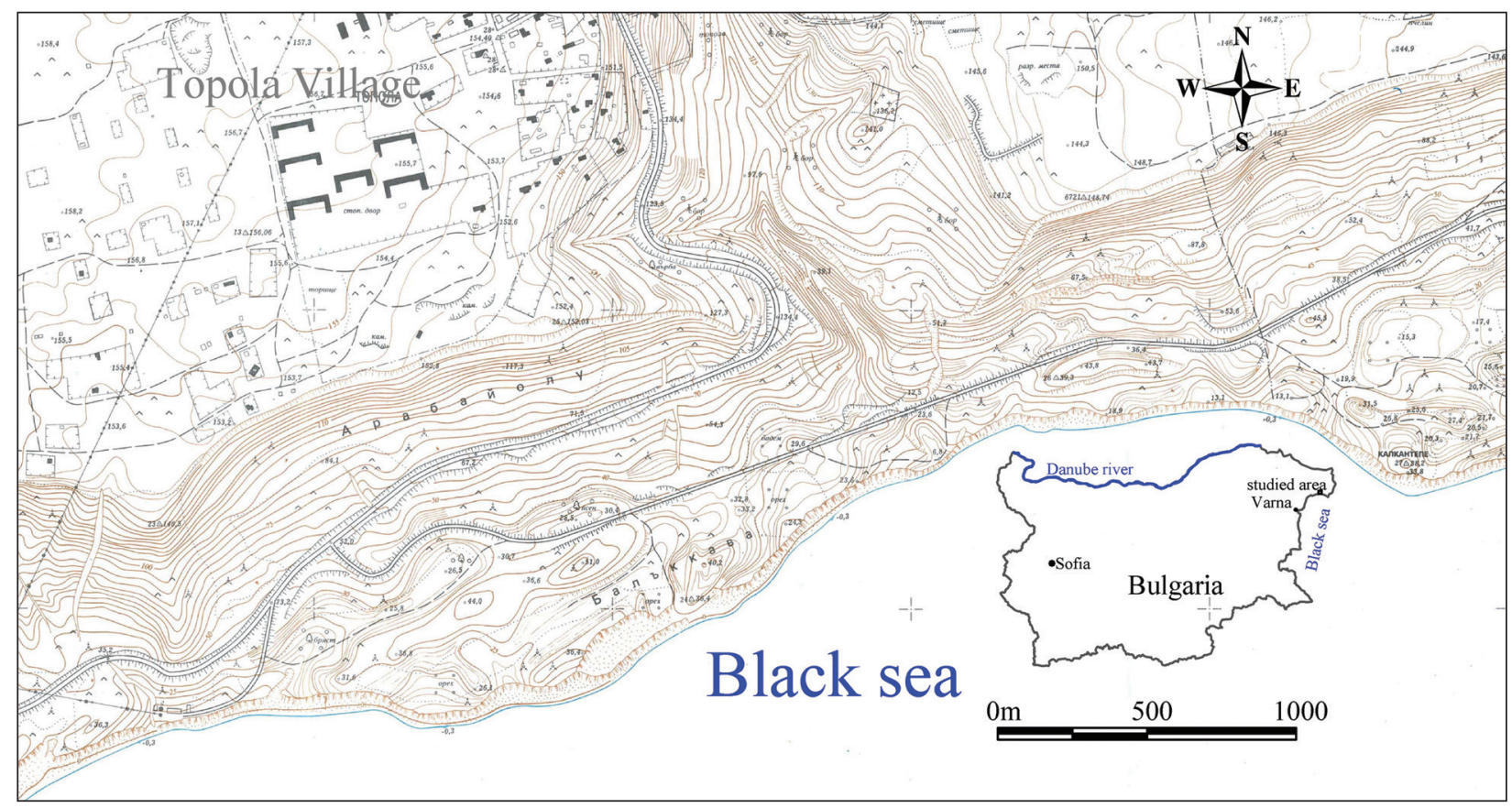

Fig. 1. Location map of the studied area.

silicate sponges (Koleva-Rekalova et al., 1996). It is covered by the Topola Formation, which mainly consists of unconsolidated aragonite sediments (aragonitites), $0.30-0.50 \mathrm{~m}$ to $1-4.8 \mathrm{~m}$ thick, alternating with light gray micritic limestones $(0.10-3.50 \mathrm{~m})$ and green calcareous clays $(0.40-3.20 \mathrm{~m})$ of Sarmatian age (Koleva-Rekalova et al., 1996) (see Fig. 2). The materials of the Topola Formation build huge landslide blocks (Evstatiev et al., 2010). The Neogen strata have a slope of $3-5^{\circ}$ ENE (Frangov and Krastanov, 2015).

\section{METHODOLOGY}

Thirty-seven samples of rock drilling cores of limestones of the Topola Formation were studied for determination of the bulk density. Additionally, 18 samples were examined for determination of dry compressive strength and eight samples were studied for determination of tensile strength in dry state. Physical and mechanical parameters of the rocks are used to determine the European standards. For the physical parameters, the EUROPEAN STANDART EN1936 (Natural stone test method - Determination of real density and apparent density, and of total and open porosity) was used. For the mechanical parameters, the EUROPEAN STANDART EN1926 (Natural stone test method - Determination of compressive strength) was applied.

\section{RESULTS}

The analysis of samples of the micritic limestone from the Topola Formation yielded the following geotech-

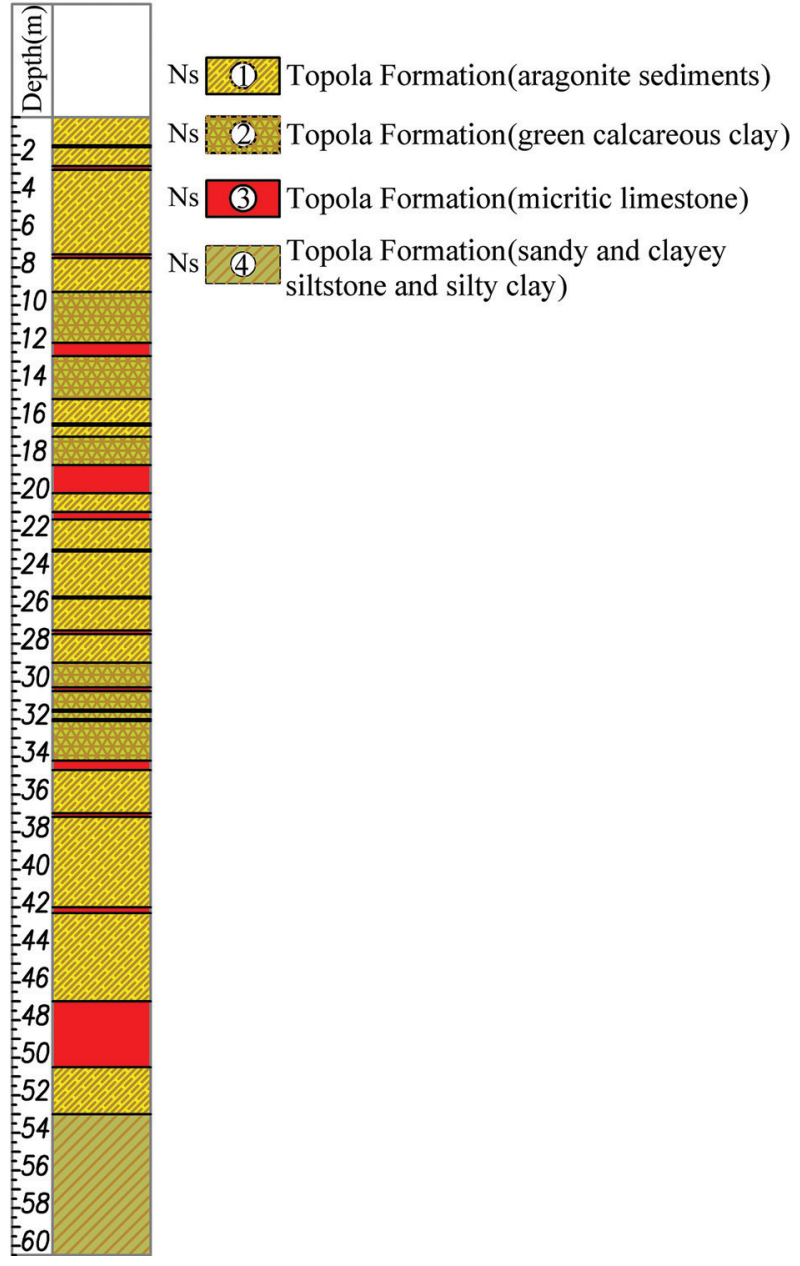

Fig. 2. Lithostratigraphic column on the Topola Formation. 

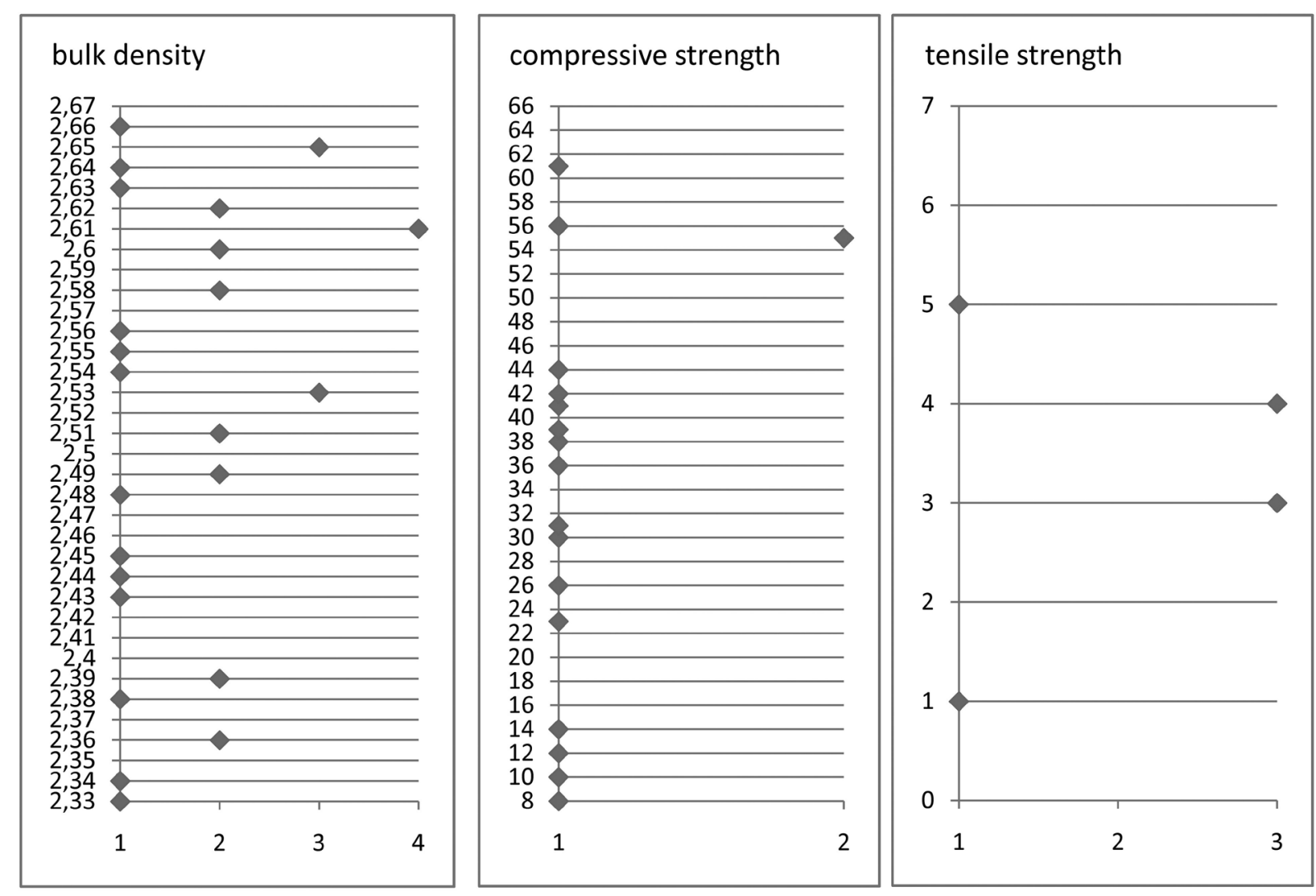

Fig. 3. Graphics of distribution by the number of values of bulk density $\left(\mathrm{g} / \mathrm{cm}^{3}\right)$, compressive strength (MPa) and tensile strength (MPa).

nical parameters: bulk density, specific density, compressive strength and tensile strength in dry state. The obtained values were processed statistically by defining the average (arithmetic values, $X$ ), the square quadratic deviation $(\sigma)$, the correction for inaccuracy $(\Delta \sigma)$, the mean deviation $\left(\sigma_{k}\right)$, the computation value of the respective parameter $(C)$ and the coefficient of variation $(V)$. For each of the parameters were drawn graphics of the distribution of the number of values (Fig. 3).

Of the studied geotechnical parametersp, only the specific density was notprocessed statistically, because only one value was done $\left(\rho_{\mathrm{s}}=2.73 \mathrm{~g} / \mathrm{cm}^{3}\right)$. A value of $\rho_{\mathrm{s}}=2.76 \mathrm{~g} / \mathrm{cm}^{3}$ is established for the rest of the Topola Formation (Evstatiev et al., 2017). Typical for the materials in the area is the increase in specific density in depth (Ivanov et al., 2015).

The values of the geotechnical parameters of the micritic limestones, at $90 \%, 95 \%$ and $99 \%$ confidence, are given in Tables 1-3.

The reliability of the results has also been confirmed by other authors (Evstatiev et al., 2017), the parameters for the density being $\rho_{\mathrm{n}}=2.35 \mathrm{~g} / \mathrm{cm}^{3}$, compressive strength of $36.0 \mathrm{MPa}$ and tensile strength of $3.7 \mathrm{MPa}$. The values obtained for these parameters at $95 \%$ confidence are the volume density $\rho_{\mathrm{n}}=2.531 \pm 0.041 \mathrm{~g} / \mathrm{cm}^{3}$,
Table 1

Determination of the geotechnical parameter bulk density

\begin{tabular}{c|c|c|c}
\hline \multirow{2}{*}{$\begin{array}{c}\text { Statistical } \\
\text { indicator }\end{array}$} & \multicolumn{3}{|c}{ Bulk density, $\mathrm{g} / \mathrm{cm}^{3}$} \\
\cline { 2 - 4 } & $90 \%$ & $95 \%$ & $99 \%$ \\
\hline$X$ & \multicolumn{3}{|c}{2.531} \\
\hline$\sigma$ & 0.10 \\
\hline$\Delta \sigma$ & 0.116 & 0.023 & 0.031 \\
\hline$\sigma_{k}$ & $2.531 \pm 0.033$ & $2.531 \pm 0.041$ & $2.531 \pm 0.058$ \\
\hline$C$ & \multicolumn{3}{|c}{3.8} \\
\hline$V, \%$ & \multicolumn{3}{|c}{} \\
\hline
\end{tabular}

Table 2

Determination of the geotechnical parameter compressive strength

\begin{tabular}{c|c|c|c}
\hline \multirow{2}{*}{$\begin{array}{c}\text { Statistical } \\
\text { indicator }\end{array}$} & \multicolumn{3}{|c}{ Compressive strength, MPa } \\
\cline { 2 - 4 } & $90 \%$ & $95 \%$ & $99 \%$ \\
\hline$X$ & \multicolumn{3}{|c}{34.333} \\
\hline$\sigma$ & 4.592 & 5.93 \\
\hline$\Delta \sigma$ & 20.518 & 21.501 & 23.571 \\
\hline$\sigma_{k}$ & $34.333 \pm 8.609$ & $34.333 \pm 10.951$ & $34.333 \pm 16.464$ \\
\hline$C$ & \multicolumn{3}{|c}{46.4} \\
\hline$V, \%$ & \multicolumn{3}{|c}{}
\end{tabular}


Table 3

Determination of the geotechnical parameter tensile strength

\begin{tabular}{c|c|c|c}
\hline \multirow{2}{*}{$\begin{array}{c}\text { Statistical } \\
\text { indicator }\end{array}$} & \multicolumn{3}{|c}{ Tensile strength, MPa } \\
\cline { 2 - 4 } & $90 \%$ & $95 \%$ & $99 \%$ \\
\hline$X$ & \multicolumn{3}{|c}{3.375} \\
\hline$\sigma$ & 0.209 & 0.45 \\
\hline$\Delta \sigma$ & 0.658 & 0.258 & 0.377 \\
\hline$\sigma_{k}$ & $3.375 \pm 0.462$ & $3.375 \pm 0.615$ & $3.375 \pm 1.049$ \\
\hline$C$ & \multicolumn{3}{|c}{13.3} \\
\hline$V, \%$ & \multicolumn{3}{|c}{}
\end{tabular}

$X$ - mean arithmetic value; $\sigma$ - mean square deviation; $\Delta \sigma-$ correction for inaccuracy; $\sigma_{k}$-corrected mean square deviation; $C$-computational value of the parameter; $V$-coefficient of variation.

the compressive strength $34.333 \pm 10.951 \mathrm{MPa}$ and the tensile strength $3.375 \pm 0.615 \mathrm{MPa}$.

\section{CONCLUSIONS}

From the statistical processing of the geotechnical parameters of the micrite limestone from the Topola Formation were computed values for volume density, compressive strength and tensile strength in the dry state. These values can be used in future calculations of slope stability in the studied area, and they are basic parameters in the compilation of geodynamic models of the landslides in the area. From the values of compressive strength and tensile strength, parameters of the angle of internal friction and cohesion by different correlation dependencies can be calculated. This, in turn, would save significant amounts of field and laboratory tests of these parameters of the micrite limestone from the Topola Formation.

Micritic limestones from the Topola Formation have an important role in determining the coefficient of safety on the slopes. They have reinforcement properties and their non-reading, when determining slope resistance, results in unreal values of the coefficient of safety. For this reason, separation and characterization in engineering and geological surveys is essential.

\section{REFERENCES}

Cheshitev, G., Chontova, Ts., Popov, N., Kojumdgieva, E. 1991. Geological map of the Republic of Bulgaria in scale 1:100 000, Balchikand Shabla map sheet. Committee on Geology, Company for Geophysical surveys and Geological mapping, Sofia.

Cheshitev, G., Chontova, Ts., Popov, N., Kojumdgieva, E. 1995. Explanatory notes for the geological map of Bulgaria in scale 1:100 000, Balchik and Shabla map sheet. Committee on Geology, Company for Geophysical surveys and Geological mapping, Sofia, 51 pp. (in Bulgarian, with English abstract).

Evstatiev, D., Evlogiev, Y., Ivanov, P., Petrova, V., Antonov, D., Nankin, R. 2010. Engineering geological settings of the seaside part of the valley of Batova River (Northern Black sea coast). Engineering Geology and Hydrogeology 25, 79-98 (in Bulgarian).

Evstatiev, D., Evlogiev, Y., Nedelcheva, M. 2017. The landslide Zapadni Karamanlii and Momchilski Rid - Balchik Black Sea Coast. Review of the Bulgarian Geological Society 78 (1-3), 3-23.

Frangov, G., Krastanov, M. 2015. Evaluation of the possibilities for construction on ancient landslide. Proceedings of the $12^{\text {th }}$ International IAEG Congress, Torino. "Engineering Geology for Society and Territory”, 267-271.

Ivanov, P., Berov, B., Dobrev, N., Yemendziev, H. 2014. Analysis of the conditions and factors for the occurrence of landslide along the Black Sea coast, Bulgaria. Bulgarian Geological Society, National Conference with international participation "Geosciences 2014", Abstracts, 103-104 (in Bulgarian).

Ivanov, P., Genov, I., Slavova, K., Dobrev, N. 2015. Geological Features of EUXRo01-1 and EUXRo03-3 loci. Engineering Geology and Hydrogeology 28, 59-67.

Koleva-Rekalova, E., Dobrev, N., Ivanov, P. 1996. Earthflows in the Baltchik landslide area, North-eastern Bulgaria. Proceedings of the $7^{\text {th }}$ International Symposiumon on Landslides, 473-478.

Koleva-Rekalova, E., Dobrev, N., Ivanov, P., Bozhinova, A. 1999. Sedimentological and engineering geological investigations of Sarmatian clays from the Balchik landslide region. Review of the Bulgarian Geological Society 60 (1-3), 103-108 (in Bulgarian). 